\title{
GHAR AL HIBASHI LAVA TUBE: THE RICHEST SITE IN SAUDI ARABIA FOR CAVE MINERALS
}

\author{
VULKANSKA JAMA GHAR AL HIBASHI: NAJBOGATEJŠE \\ NAHAJALIŠČE JAMSKIH MINERALOV V SAUDSKI ARABIJI \\ PAOLO FORTI ${ }^{1} \&$ ERMANNO GALLI ${ }^{2} \&$ ANTONIO ROSSI $^{2}$ \\ $\&$ JOHN PINT $^{3} \&$ SUSANA PINT $^{3}$
}

\footnotetext{
${ }^{1}$ Italian Institute of Speleology, University of Bologna, Italy

${ }^{2}$ Department of Earth Sciences, University of Modena and Reggio Emilia, Italy

${ }^{3}$ Saudi Geological Survey, Jeddah, Saudi Arabia
} 


\section{Abstract}

UDC: $551.215(532): 552.3$

\section{Paolo Forti \& Ermanno Galli \& Antonio Rossi \& John Pint \& Susana Pint: Ghar Al Hibashi lava tube: the richest site in Saudi Arabia for cave minerals}

Several large lava tubes have been explored and mapped in different lava fields around the Saudi Arabia. One of the largest is Ghar Al Hibashi, located in the Harrat Buqum-Nawasif lava field. It mainly consists of a huge rectilinear gallery (over $400 \mathrm{~m}$ long and $15 \mathrm{~m}$ wide) the access to which is through a small vertical pit reaching a side corridor. The cave was long used as a shelter for bats, hyenas, wolves and foxes. Therefore the entire cave floor, consisting of locally thick uncemented sand, is scattered with a great amount of bones and coprolites, while some rather large guano deposits are also found. Some of these guano deposits caught fire, which partially burnt the bones overlaying them as well. The only true speleothems consist of a few small yellow translucent stalactites. During three expeditions in 2003, a few samples of secondary chemical deposits were collected inside this lava tube to be analysed from the mineralogical point of view. Despite the scarcity of these samples, at least 19 different minerals have already been detected, most of which are related to the biogenic mineralization of bones and guano deposits. Three of them, pyrocoproite, pyrophosphite and arnhemite are extremely rare organic compounds strictly related to the guano combustion, which have been observed until now only in a few caves in Africa. Thanks to these findings Hibashi lava tube is not only the most important volcanic cave of Saudi Arabia but also by far the richest mineralogical shelter of the country. Therefore this research, which is far from coming to an end, confirms the recently advanced opinion that amongst the different cave environments, volcanic cavities are very favourable for the development of different minerogenetic mechanisms.

Keywords: Cave minerals, lava tubes, guano combustion, Ghar Al Hibashi, Saudi Arabia.

Izvleček

UDK: 551.215(532):552.3

Paolo Forti \& Ermanno Galli \& Antonio Rossi \& John Pint \& Susana Pint: Vulkanska jama Ghar Al Hibashi: najbogatejše nahajališče jamskih mineralov v Savdski Arabiji

V Savdski Arabiji je bilo raziskanih in izmerjenih več velikih vulkanskih jam v različnih poljih lave. Ena največjih je Ghar Al Hibashi na polju lave Harrat Buqum-Nawasif. To je v glavnem raven rov (400 m dolg in $15 \mathrm{~m}$ širok), dostopen skozi majhno brezno, ki se odpira v stranskem rovu. Jama je dolgo služila za skrivališče netopirjem, hijenam, volkovom in lisicam. Zaradi tega je dno jame, deloma iz debelih plasti nesprijetega peska, prekrito s številnimi kostmi in koproliti ter razmeroma velikimi kupi gvana. Nekateri so se bili vneli, zaradi česar so deloma zgorele tudi na njih ležeče kosti. Edine prave kapnike predstavlja nekaj majhnih, rumenih in prosojnih stalaktitov. Tekom treh odprav 2003 je bilo iz jame vzetih nekaj sekundarnih kemičnih odkladnin za mineraloške preiskave. Kljub majhnemu številu vzorcev je bilo do sedaj zaznanih vsaj 19 različnih mineralov, največ takih, ki so povezani z biogeno mineralizacijo kosti in gvana. Trije od teh, pyrocoproite, pyrophosphite in arnhemite, so izredno redke organske spojine, izključno vezane na goreči gvano. Do danes so bili ti minerali znani le iz nekaj jam v Afriki. Zahvaljujoč tem odkritjem ni jama Hibashi le najpomembnejša vulkanska jama v Savdski Arabiji, ampak tudi tamkajšnje daleč najbogatejše mineraloško nahajališče. Zato te raziskave, ki še zdaleč niso končane, potrjujejo novejše domneve, da so v jamskem okolju prav vulkanske jame najprimernejše za razvoj različnih mineralogenih mehanizmov.

Ključne besede: jamski minerali, jama v lavi, gorenje gvana, Ghar Al Hibashi, Savdska Arabija. 


\section{INTRODUCTION}

The exploration of natural caves in Saudi Arabia started only a few decades ago (Pint, 2003, 2004; Al Shanti, 2004) and it is still in progress even if a few karst areas are now rather well known. Saudi Arabia hosts some huge lava fields (Fig. 1) in which a considerably high number of lava tubes develop. However, the systematic exploration of lava tubes of this Country started only a couple of years ago and several rather large lava tubes have already been explored and mapped in different lava fields around the country.

One of the largest lava tubes of Saudi Arabia is Ghar Al Hibashi, located in Harrat Buqum-Nawasif lava field: it mainly consists of a huge rectilinear gallery (over $400 \mathrm{~m}$ long and $15 \mathrm{~m}$ wide) the access to which is through a small vertical pit reaching a side corridor (Fig. 2).

The cave was used long since as shelter by different wild animals (bats, hyenas, wolves and foxes at least), and more recently as a corral for sheep and goats. Therefore the entire cave floor, consisting of a locally thick layer of uncemented sand (Fig. 3), is scattered with numerous bones and coprolites, while two rather large guano deposits are also found. Some of these guano deposits caught

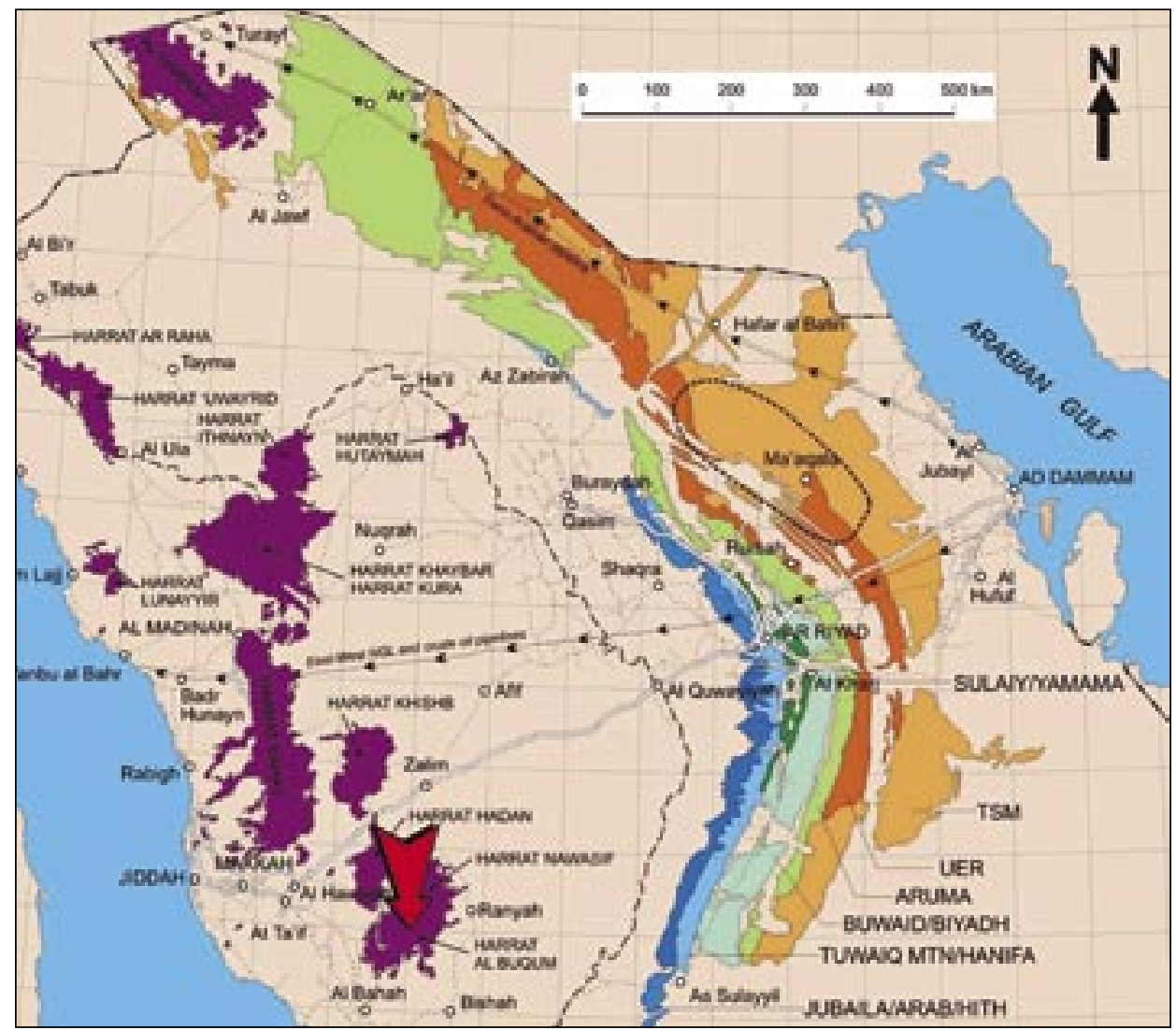

Fig. 1: Geological map of Saudi Arabia with the location of the main lava fields. The arrow points to the location of Hibashi cave. 


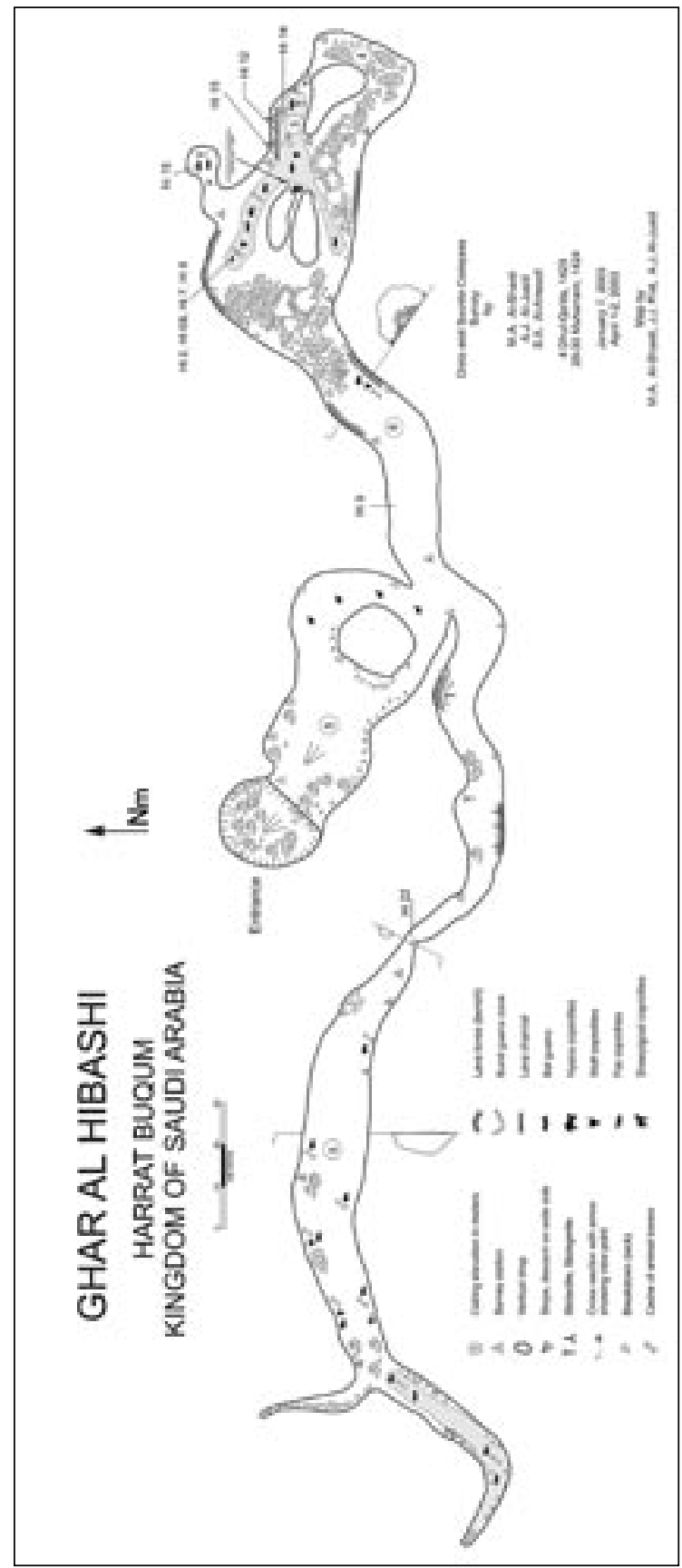

Fig. 2: Plan of Hibashi cave in which the location of the analysed samples are reported. fire, which partially burnt the bones overlaying them (Fig. 4) as well. The only true speleothems consist of a few small yellow translucent stalactites hanging from the ceiling of the cave (Fig. 5).

During three different expeditions all carried out in 2003, a few samples of secondary chemical deposits were collected inside this lava tube to be analysed from the mineralogical point of view.

In the present paper, after a short presenation of the experimental methods, all the sampled specimens are described from the morphological and mineralogical point of view. Then follows a discussion on the genetic mechanisms which allowed the formation of the rare minerals association found in Hibashi Cave.

\section{EXPERIMENTAL}

A total of 11 samples were taken from different locations inside the cave (Fig. 2). A detailed analysis of all the samples by the stereoscopic microscope was performed to distinguish and to separate the different mineralogical phases eventually present in each sample. This analysis permitted the discarding of one sample (Hi 10A) consisting of a wholly biogenic structure (nests of some insect larvae). Then the single phases were analysed by means of powder X-ray diffraction (Philips PW 1050/25), when the material was quantitatively sufficient and homogeneous, or by a Gandolfi camera (Ø: $114.6 \mathrm{~mm}$, exposition: $24 / 48 \mathrm{hrs}$ ), when the material was 


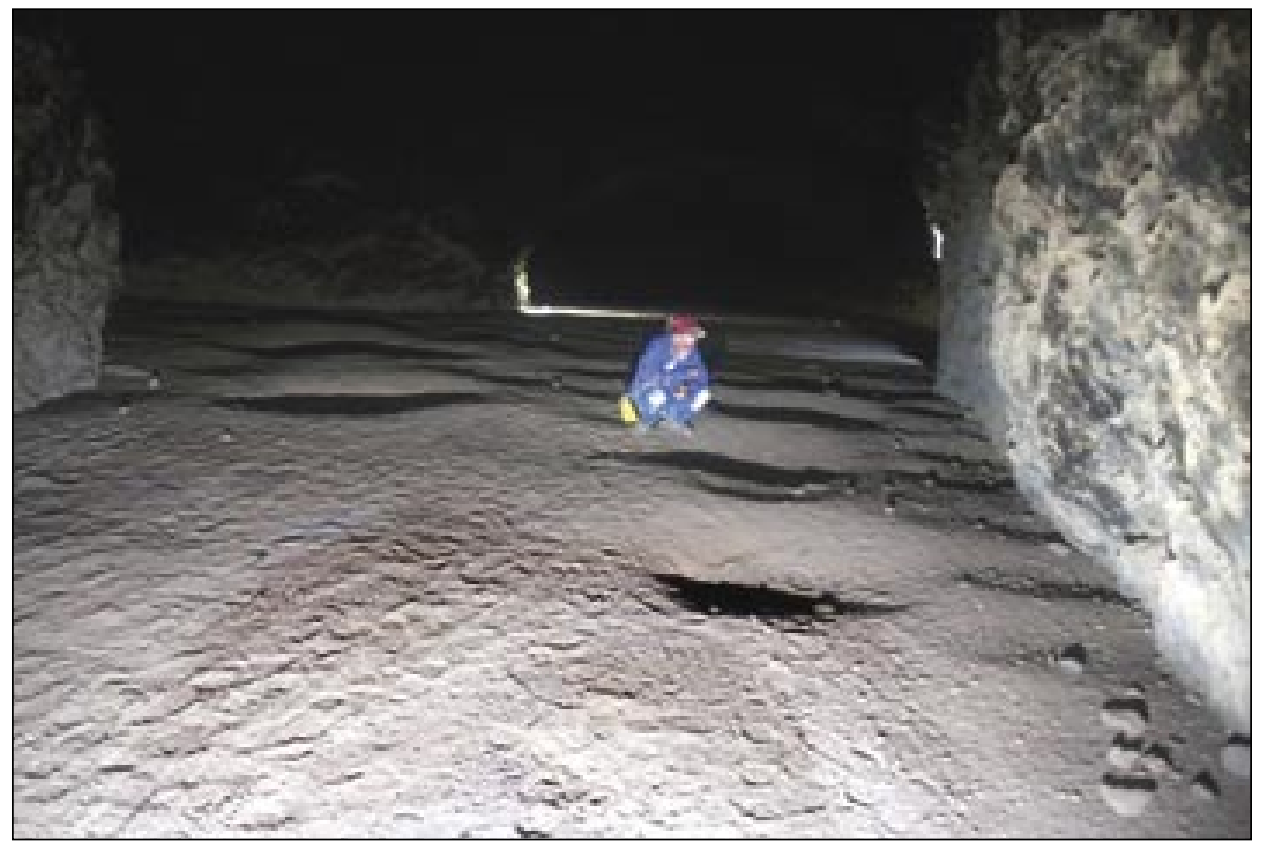

Fig. 3: General view of the cave floor consisting of uncemented dust.

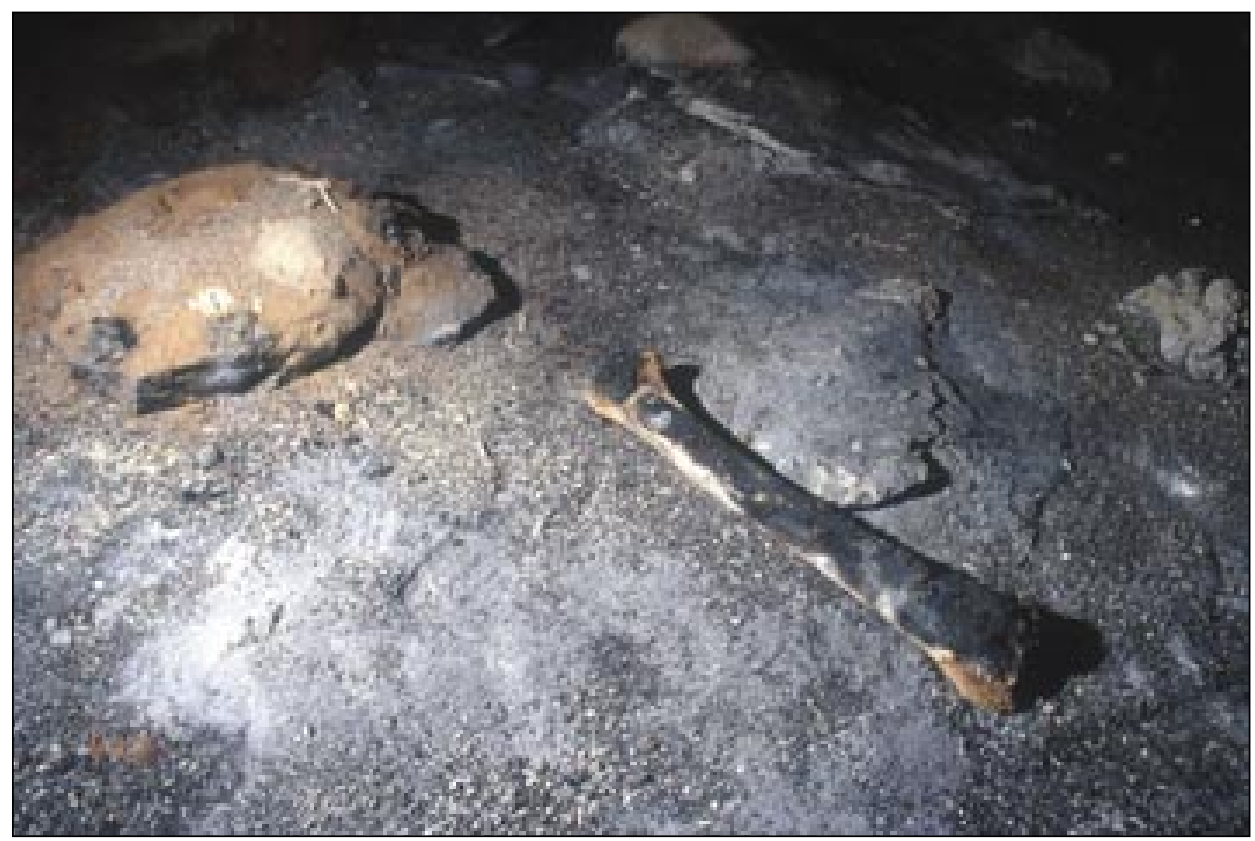

Fig. 4: A portion of the cave floor where the guano firing occurred. 


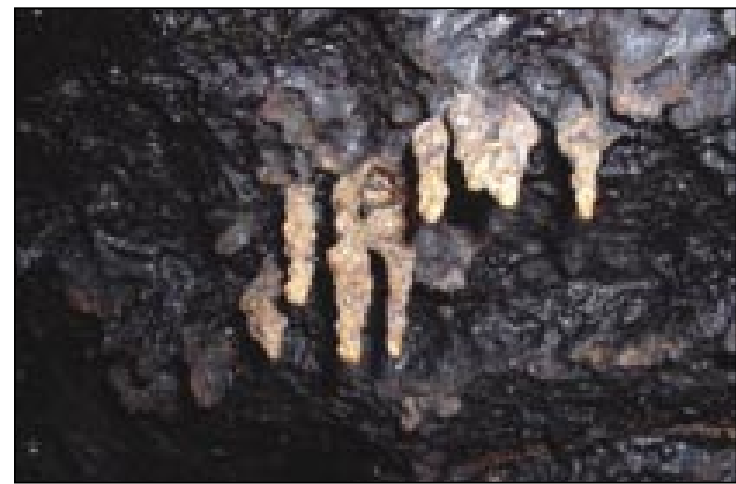

Fig. 5: Close view of some of the few real stalactites within the Hibashi cave.

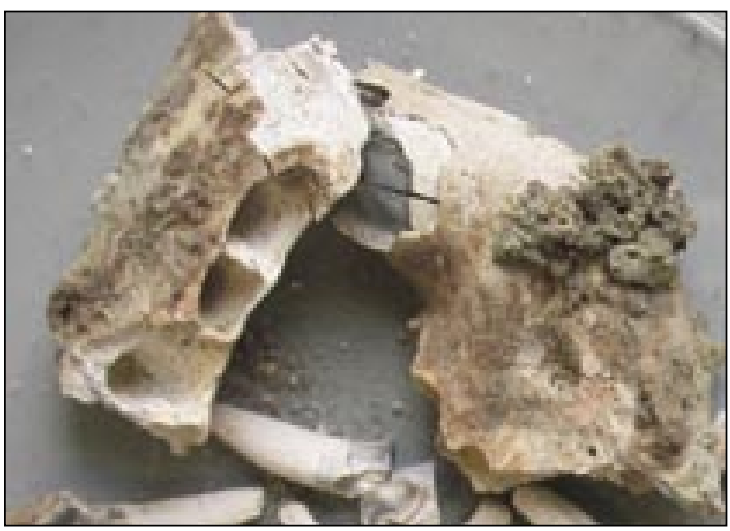

Fig. 6: Fragments of a jaw with a few teeth partially covered by a scoriaceous crust.

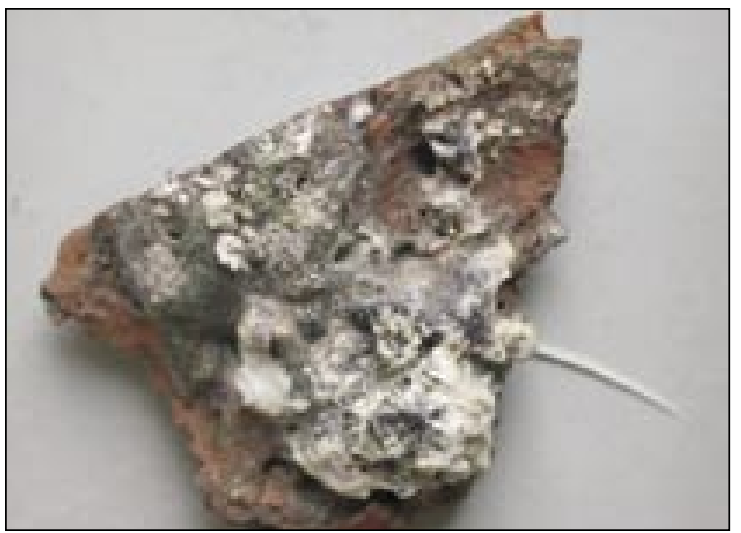

Fig. 7: Fragment of volcanic rock partially covered by a scoriaceous crust. scarce or inhomogeneous. The experimental conditions were always: $40 \mathrm{kV}$ and $20 \mathrm{~mA}$ tube, $\mathrm{CuK} \alpha \mathrm{Ni}$ filtered radiation $(\lambda=1.5418 \AA)$. The same samples analyzed in the Gandolfi camera were later used to obtain images and chemical qualitative analyses through an electron scanning microscope (SEM Philips XL40) with an electronic microprobe (EDS - EDAX 9900) at the "Centro Interdipartimentale Grandi Strumenti" of the Modena and Reggio Emilia University. The petrographic identification of rock sample Hi8 was done on a thin section using a polarizing microscope.

\section{INVESTIGATED SAMPLES}

A short morphological description of each sample together with the list of the detected minerals is here reported.

Sample Hi2 - [Burnt wolf scat] Partially burned coprolites $(\varnothing=35 \mathrm{~mm})$ as a consequence of a guano-firing. The following minerals have been detected: quartz, plagioclase, calcite, dolomite. Quartz and feldspar are residual, coming probably from the loess deposited inside the cave, which is rich in these minerals. Calcite and dolomite should be secondary in origin being absent in the lithology of the whole lava field.

Sample Hi6b - [Ash from burnt zone] - Heterogeneous sample consisting of dusty brown sediment associated with numerous bone fragments partially covered by secondary crusts. These vitreous, semi-transparent globular scoriaceous crusts are clearly a melting product caused by the guano combustion. The following minerals have been detected: aphthitalite, arcanite, carbonate-hydroxylapatite, chlorapa- 
tite, hydroxylapatite, opal-C, pyrocoproite, pyrophosphite, quartz and whitlockite.

Sample 7 - [Bone from burnt zone] - Fragment of a jaw with a few teeth $(50 \times 30 \times 9 \mathrm{~mm})$ : inside the jaw the progressive transition from the preserved partially porous bone material to the external vitreous semi-transparent globular saccaroid crusts is evident, which gave rise also to small coralloids (Fig. 6). The thickness and the colour of this layer change side by side, but the material is identical to that described for sample Hi6b. The teeth and some of the coralloid fragments are partially covered by euhedral prismatic vitreous transparent crystals, which are also arranged in concentric layers inside the teeth. The following minerals have been detected: anhydrite, aphthitalite, arcanite, calcite, carbonate-apatite, chlorapatite, halite, hydroxylapatite, opal-C, palygorskite, pyrophosphite, pyrocoproite, quartz, urea and whitlockite.

Hi8 - [From burnt zone floor] - Fragments of the reddish volcanic rock (Fig. 7) associated with partially fired uncemented milky white to pale sky-blue grains: they consists of a vescicolar dolerite rock rich in euhedral olivine and partially isoriented plagioclase crystals, with intergranular texture. The following minerals have been detected: anhydrite, archerite, arnhemite, opal-C, pyrocoproite, pyrophosphite, pyroxene, quartz, urea, whitlockite. Quartz and pyroxene are residual in this sample.

Sample Hi9 - [Dirt sample from $\mathbf{- 7 0} \mathbf{~ c m}$ below floor]: Sand from the cave floor: fine-grained heterogeneous dark brown sand. The following minerals have been detected: chlorite, feldspar, illite, quartz. Chlorite, feldspar and quartz are surely residual, coming from the desert sand and/or the lava tube wall while illite may be also secondary in origin.

Sample Hi10A - Wholly organic material consisting of the remains of sub-actual nests of insect larvae. No minerals at all have been detected.

Sample Hi12 - [Content of lava channel ]: it is an incoherent middle to fine grained hazel-brown sample, which may be subdivided into different portions: a) thin, dark brown to mother of pearl luster, sometimes semi-transparent crusts (probably organic remains of bush or trees); b) bended pale transparent crusts and small tubes; c) lemon pale yellow greasy grains; d) orange to brown grains; e) semi-transparent tubular fragments; e) dark brown vitreous to wax spheroidal grains. The following minerals have been detected: aphthitalite, arcanite, biphosphammite, quartz.

Sample Hi13 - [Lower extreme content of lava channel ]: dark incoherent material with graphite luster and variable grain size. The following minerals have been detected: aphtitalite, arcanite, biphosphammite.

Sample Hi14 - [Burnt coating on ceiling]: soft sticky pith-dark fragment. The following minerals have been detected: aphthitalite, arcanite, biphosphammite.

Sample Hi15 - [Sticky stalactite between stations 18w-19w] - Small fragment of a stalactite (20x10 mm) consisting of sticky microcrystalline hazel-brown material partially covered by small vitreous semi-transparent prismatic crystals. The following minerals have been detected: arcanite, biphosphammite, opal-C, urea.

Sample Hizz - [Sticky stalactites near station 12w]: Small stalactite fragments consisting of sticky, poorly cemented, hazel-brown to brown material. The following minerals have been detected: arcanite, biphosphammite, chlorapatite, niter, opal-C, quartz, urea, whitlockite.

\section{DESCRIPTION OF THE DETECTED MINERALS}

A common characteristic of nearly all the samples is the strict interconnections of many of the 
mineralogical phases, which made extremely difficult and sometimes totally hindered separating them and putting in evidence the specific morphological peculiarities of each phase: this was particularly true for the samples coming from the burnt zone.
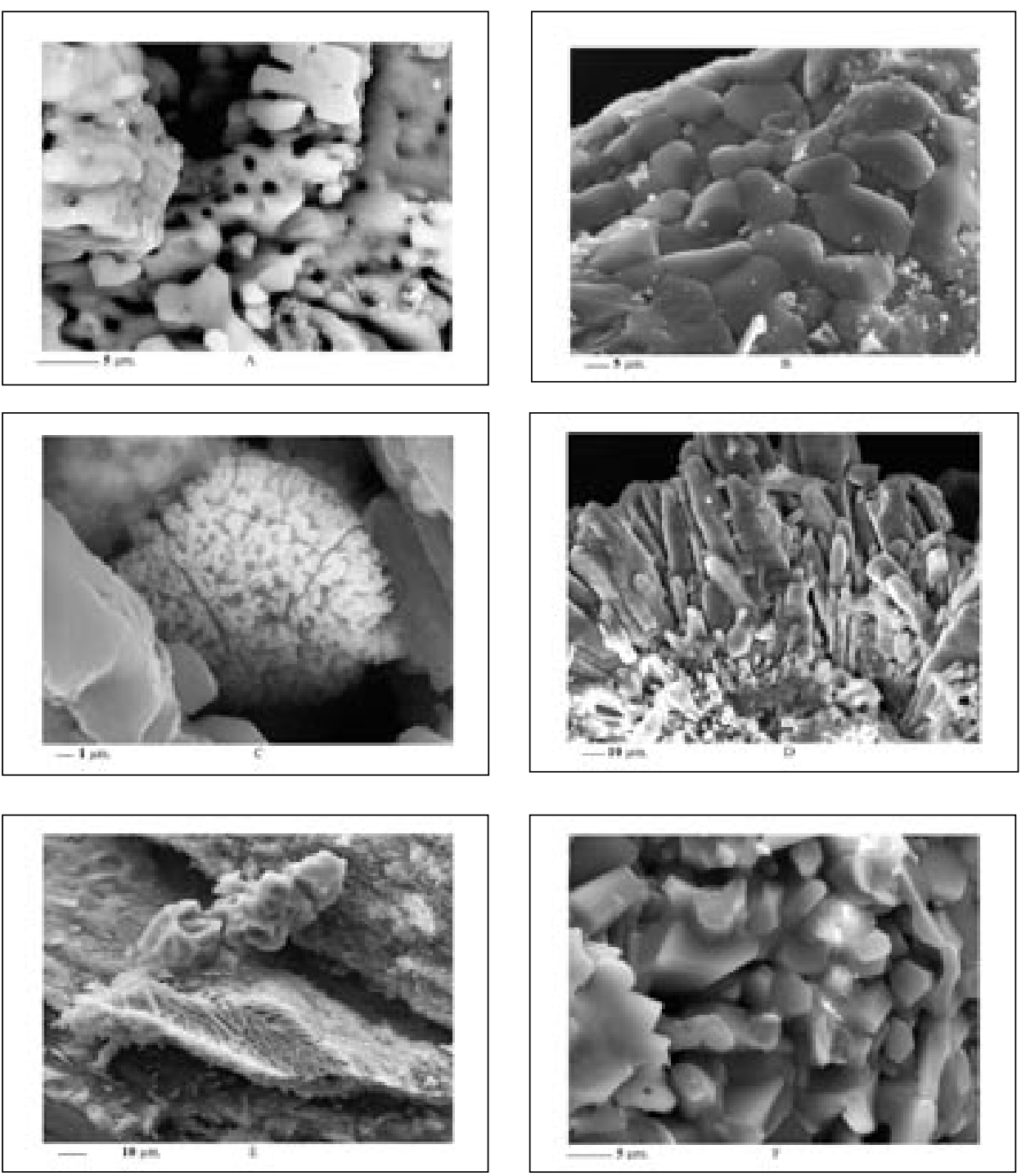

Fig. 8: SEM images of Hibashi cave minerals: A- anhydrite with evident corrosion/redissolution holes (Hi8); $B$ - aphtitalite crystals with small calcite grains (Hi7); $C$ - arcanite sub-spherical aggregate (Hi12); D- diadem aggregate of prismatic tetragonal crystals of biphosphammite (Hizz); E- fibrous fish-bone shaped crystals of chlorapatite and elongated aggregate of calcite crystals (Hi7); F- pseudo-hexagonal crystals of chlorapatite. 
Anhydrite- Rare, found in the Hi7 and Hi8 samples. It occurs in small earthy sub-spherical aggregates of tabular milky-white ovoidal elements, with the external surface often punched by many corrosion holes (Fig. 8-A)

Aphthitalite - It is one of the most common phases. It has been detected almost always associated with biphosphammite in honey yellow to dark brown subspherical grains and/or vitreous fragments in the samples Hi6b, Hi7, Hi12, Hi13, Hi14. In Hi7. It had been observed also as a thin film over apatite and as thin to thick ovoidal grains and as crusts in Hi8 (Fig. 8-B).

Arcanite $\left[\mathrm{K}_{2}\left(\mathrm{SO}_{4}\right)\right.$ - orthorhombic] - It has been found several times as emi-transparent to lemon yellow vitreous crusts, mixed with chlorapatite, opal-C, pyrocoproite and pyrophosphite in samples Hi6b, Hi7 or in plastic microcrystalline honey yellow small aggregates mixed with aphtitalite and biphosphammite in samples Hi12, Hi13, Hi14, Hi15, Hizz. In sample Hi12 this mineral has a peculiar cauliflower habit consisting of pale hazel-brown micro-grains (Fig. 8-C).

Archerite - This mineral is very rare in Hibashi cave: it has been observed as small vitreous semi-transparent crusts over bone fragments in the sample $\mathrm{Hi} 7$ and as pale-yellow vitreous coralloids in Hi8. In both these occurrences it is strictly associated to pyrocoproite and pyrophosphite.

Arnhemite - Extremely rare. This mineral was first described by Martini (1994a) and submitted to CNMMN but not approved before its publication (Jambor and Roberts, 1999). In Arnhen cave (Namibia) arnhemite is one of the most common crystalline phases and occurs as aggregates of flakes, up to $50 \mu \mathrm{m}$ (Martini 1994a). In the Hibashi lava tube it was found exclusively in sample Hi8, where it was detected only once: it is strictly associated with pyrophosphite and opal-C. Its occurrence has been confirmed by X-ray analysis while it was impossible to define its crystal habit. In his paper Martini supposed that arnhemite of Arnhem Cave is not a direct product of guano combustion, but it is the result of hydration processes of $\mathrm{Na}-\mathrm{K}$ phosphate precursors developed at high temperature. If the Martini hypothesis is correct the scarcity of arnhemite in the Hibashi lava tube may be the consequence of the much dryer environment of this lava tube with respect to the cave in Namibia and/or to an insufficient time span after the guano-firing.

Biphosphammite - It is the most common mineralogical phase in the samples Hi12, Hi13, Hi14, Hi15 and Hizz, all coming from cave sectors not directly affected by guano combustion . It normally consists of yellow to orange to hazel-brown small smooth spherical grains but sometimes gives rise to aggregates of vitreous elongaed prismatic crystals (samples Hi12, Hi14, Hi15 and Hizz) or to pitch-dark grains in the Hi13 sample. It is associated with aphtitalite, arcanite, opal-C and urea (Fig. 8-D).

Calcite - Very rare as true cave mineral, it has been found only in sample Hi7 where it is present as a flat aggregate of globular crystals overlaying a fibrous aggregate of chlorapatite or in very small fragments associated with aphtitalite (Fig. 8-E). It is more common as a detritic phase in the Hi2 sample where it gives rise to several millimetre rounded grains.

Carbonate-hydroxylapatite - It is present in Hi6b and Hi7 samples being one of the phases of the thin transparent to semi-transparent glassy layer covering a milky-white bone fragment, which has been partially vitrified by the combustion.

Chlorapatite - It is present in the Hi6b, Hi7 and Hizz: in this cave it is the most common mineral of the apatite group. It occurs as honey-yellow thin elongated iso-oriented fibers or in a fish-bone arrangement within small bone cavities (Fig. 8-E, F; 9-A).

Halite - Even if the chlorine is a fairly common element within all the analysed samples, this 
mineral has been detected only in sample Hi7. It gives rise to globular, sometime flat crystals with rounded edges inside a pale sky blue semi-transparent coralloid where it is associated with chlorapatite (Fig. 9-A).

Hydroxylapatite - Identified in samples Hi6b and $\mathrm{Hi} 7$ within bone porosity to compact fragments
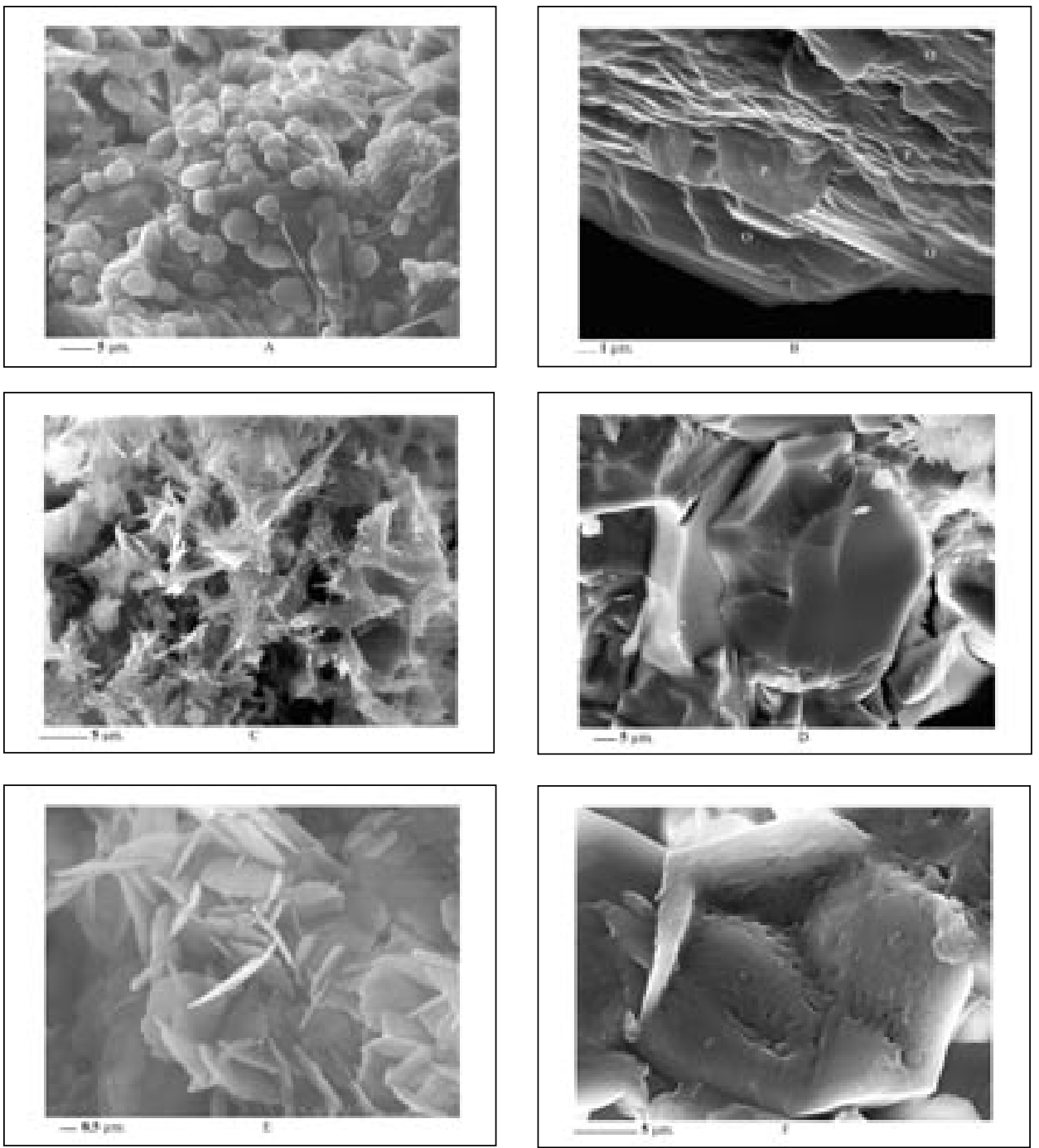

Fig. 9: SEM images of Hibashi cave minerals: A- globular crystals of halite on chlorapatite (Hi7); $B$ Admixture of platy indented crystals of pyrocoproite ( $p$ ) and tabular opal-C; $C$ - snow-white soft tufts of acicular crystals of palygorskite (Hi7); D - pyrocoproite crystals with concoidal fracture (Hi8); E- interpenetrating group of platy indented pyrocoproite crystals; $F$-close view a pyrocoproite pseudo-hexagonal aggregate of platy indented laminar crystals with helicoidal structure (Hi8). 
partially transformed into whitlockite.

Niter - Very rare, observed just once and only in the Hizz sample, strictly associated with biphosphammite.

Opal-C - Identified in semi-transparent to pale yellow vitreous globular or coralloid crusts in
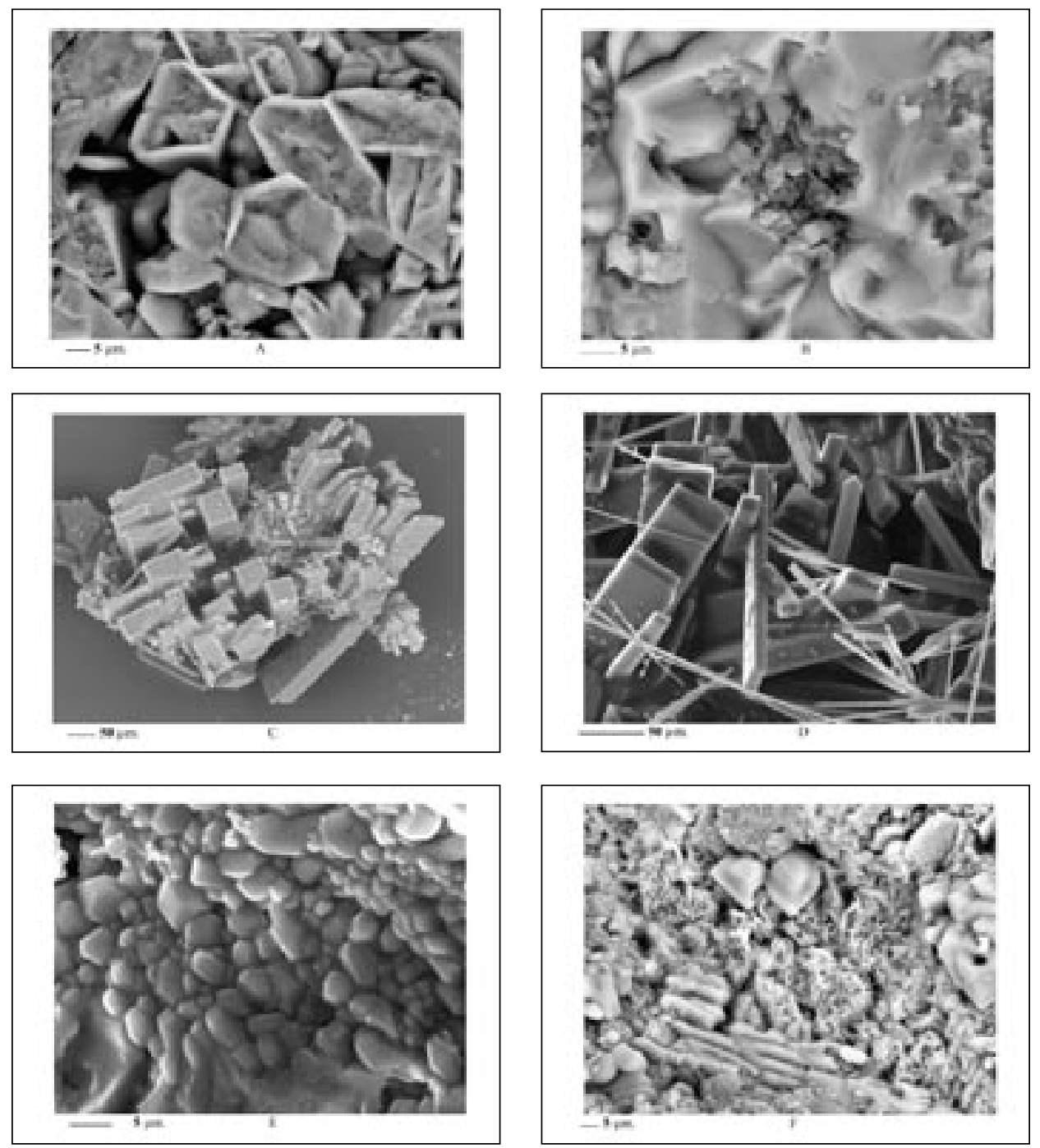

Fig. 10: SEM images of Hibashi cave minerals: A- pyrocoproite pseudo-hexagonal aggregates of platy indented crystals (Hi8); B-compact pyrophosphite with small opal-C spheres inside the hole (Hi8); $C$ tetragonal prismatic crystals of urea (Hi15); D- tetragonal prismatic crystals of urea with thin elongated crystals of a still unknown compound (Hi15); E - crust of globular crystals of Mg-rich whitlockite (Hizz); $F$-felt of thin platy crystals of pyrocoproite with large auhedral still undetermined crystals (Hi8). 


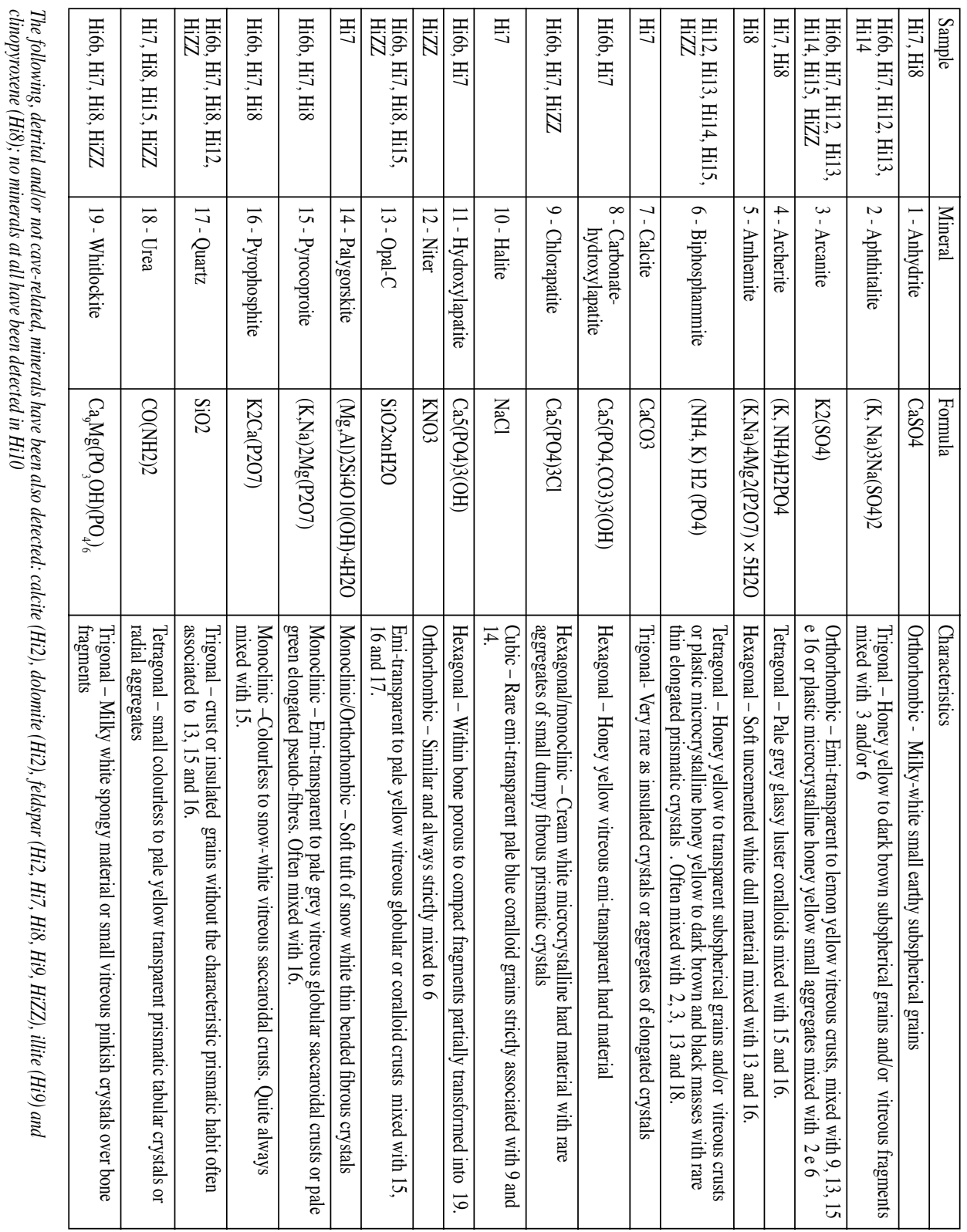

Tab. I - Identified cave minerals and their distribution within the cavity: Hi2: burnt wolf scat; Hi6b: ash from burnt zone; Hi7: bone from burnt zone; Hi8: volcanic rock from burnt zone; Hi9: dirt sample from $-70 \mathrm{~cm}$ below floor; Hil0: nest of insect larvae; Hi12: content of lava channels; Hi13: lower extreme content of lava channel; Hil4: burnt coating on ceiling; Hi15: sticky stalactite between stations 18w-19w; HiZZ: sticky stalactites near station 12w. 
samples Hi6b, Hi7, Hi8, Hi15, Hizz samples. It is strictly associated with K-phosphates and quartz, from which it is distinguishable due its flat lenticular shape. Occurs as microblades identical to those which are mixed together (Fig. 9-B, 10-B). Its genesis is evidently simultaneous to that of pyrocoproite and pyrophosphite and therefore strictly related to guano firing. Its detection was made by chemical analyses and it was confirmed by the shape of the $\sim 22^{\circ} 2 \vartheta$ peak and of the other broad peaks which differentiate this mineral with respect to cristobalite and opal-CT (Jones \& Segnit,1971; Smith, 1998). Unfortunately it was impossible to define the $\mathrm{H}_{2} \mathrm{O}$ content due to the dimension of the small blades and to its strict interconnection with the other mineralogical phases.

Palygorskite - monoclinic/orthorhombic] - Very rare, identified only in the Hi7 sample. It consists of snow-white soft tufts of densely interlaced thin elongated vitreous fibres (Fig. 9-C).

Pyrocoproite - It is one of the more common minerals within the samples collected in the burnt zone (Hi6b, Hi7 ed Hi8). The pyrocoproite was firstly reported by Martini (1997) in Arnhem Cave but it has never been submitted to the CNMMN: among eight samples studied by Martini (1997), only one was not completely altered in arnhemite. The Hibashi pyrocoproite is present in transparent colourless smooth crusts as interlaced or iso-oriented pseudo-hexagonal and/or tabular crystals with indented edges (Fig. 9-D, E, F; 10-A). The relative abundance of this mineral in Hibashi Cave with respect to Arnhem Cave confirm the hypothesis that in this lava tube, the process to form arnhemite was hindered.

Pyrophosphite - This is as common as the previous one, to which it is always strictly associated so as to avoid their partition. It has been found in Hi6b, Hi7 and Hi8 samples. This mineral was described for the first time by Martini (1994a) in Arnhem Cave where it occurs as anhedral, ovoidal grains up to $50 \mathrm{~mm}$ across, white in colour, vitreous luster, soft: it has not been approved by CNMMN. No insulated grains of this mineral have been observed in the Hibashi samples; it is present only in the vitreous crusts over the bone and/or rock fragments (Fig. 10-B).

Quartz - Fairly abundant, observed within Hi6b, Hi7, Hi8, Hi12 and Hizz where it occurs as thin crusts associated to opal-C, pyrocoproite and pyrophosphite or in insulated irregular grains, without the characteristic prismatic bipiramidal habit. It has been also observed as vitreous microspheres with their surface partially covered by chlorapatite.

Urea - Detected in the Hi7, Hi8, Hi15 and Hizz samples, it is surely the crystalline phase occurring with the best defined habit among all the minerals of the Hibashi lava tube. It always consists of small colourless to pale yellow transparent tetragonal prismatic crystals isolated or in radial aggregates (Fig. 10-C, D).

Whitlockite - Abundant in the Hi6b, Hi7ed Hi8 samples of the burnt zone and also in the Hizz sample which was taken from a zone not directly affected by guano-firing. In all but one, the occurrence the mineral was a $\mathrm{Mg}$-rich variety of whitlockite. It has been observed within a milky white spongy material or small vitreous pinkish crystals over bone fragments and it consists of aggregates of sub-spherical grains having different dimensions. (Fig. 10-E).

Rather interesting is a still not determined material which normally occurs as tiny vitreous luster, transparent to colourless, flakes or as small milky-white to silk luster spheres (Fig. 10-F), constantly characterized by interferences at $\sim 11.8,9.3,5.8,3.9,2.9$ and $1.82 \AA$. The shape and the chemical composition of this material are still under study and is very similar to the arnhemite described by Martini (1994a, 1994b, 1997) in Arnhem Cave (Namibia). It may be an intermediate phase between pyrocoproite and arnhemite with respect to the $\mathrm{H}_{2} \mathrm{O}$ content and the dimension of the elemental cell. 
Unfortunately due to the scarcity of the sample and to the difficulty in separating it from the other mineralogical phases, it was impossible until now to obtain a sufficient amount of pure material to make its complete mineralogical definition.

Finally the following, detrital and/or not cave-related, minerals have been also detected: calcite (Hi2), dolomite (Hi2), feldspar (Hi2, Hi7, Hi8, Hi9, Hizz), illite (Hi9) and clinopyroxene (Hi8). They always consists of more or less rounded millimetre polished grains. No minerals at all have been detected in Hi10

\section{DISCUSSION}

Despite the scarcity of analysed samples, at least 19 different cave minerals have been detected, most of which are related to dejecta of animals or to biogenic mineralization of bones and guano deposits (Tab. I). Many of the detected minerals are well known in cavern environment but a few are really unusual. In reality, the total number of detected minerals is higher (23) but four of them (dolomite, feldspar, illite and pyroxene) have not been inserted in the list of Hibashi cave minerals of Table I due to a reasonable doubt that they may not have a cave-related origin. The residual and/or detrital origin of two of them (feldspar and pyroxene) is sure, being components of the hosting rock, while the other two may be also secondary in origin.

Illite is a well known cave mineral but it may also develop due to weathering of silicates on the surface or it may be residual. The location of the sample (Hi9) about $70 \mathrm{~cm}$ below the floor of the cave may suggest the evolution of this mineral directly within the lava tube. In fact it is difficult to justify such a deep location for a deposit which had to be brought into the cave by winds, when the upper part of these sandy deposits is composed by normal fragments of lava (which are surely airborn sediment).

The problem of the origin of dolomite is even more complex: in fact carbonate outcrops are absent in the whole volcanic region and the dry climate avoids weathering of the $\mathrm{Ca}^{++}$and $\mathrm{Mg}^{++}$ions from lava by seeping and/or condensation water within the cave. Therefore the single possible explanation for its presence is related to the cave frequentation by carnivores, which is clearly testified by bones and other remains. Calcite grains found within coprolites are probably detrital. Anyway at least in one occurrence (Hi7) a calcite crystal was clearly of recent chemical deposition and therefore calcite was inserted in the list of cave minerals of the Hibashi lava tube. Dolomite grains of Hi2 are very similar in shape and size to the calcite ones but in no occurrence was it possible to detect clearly its genetic mechanism. In reality, its detrital origin is probable but not sure. In fact bones cannot directly supply this mineral, and dolomitic outcrops are very far. Anyway at the moment there is no evidence of its deposition during the mineralization of the coprolites inside the cave and therefore maybe that dolomite was a by product of digestion processes. In fact, digestion processes may lead to the mobilization of calcium and magnesium from bones and/or meats which immediately or a little later were deposited as calcite and/or dolomite within the excrement and therefore the genesis of dolomite would be absolutely uncontrolled by the cave environment.

This hypothesis seems to be confirmed by the fact that the single sample in which calcite and dolomite were found (together with feldspar) was Hi2, consisting of a partially burnt wolf scat, in which no other minerals (amongst those normally related to the biogenic mineralization of guano and coprolites like phosphates and/or sulphates) have been observed. The absence of the typical 
association of guano minerals is an indirect proof that the combustion took place when the wolf scat was not yet heavily transformed by the slow biogenic processes characteristic of the cavern environment and therefore all its organic content was transformed into volatile compounds by fire.

For this reason dolomite, and perhaps also calcite, should not be considered true cave minerals.

Amongst the 19 cave minerals of the Hibashi the highest number (9) are phosphates, 3 sulphates, 3 silicates, and 1 each carbonate, nitrate chloride and organics compound respectively: but the origin of most of them was controlled by the biogenic reactions related to the different steps in the mineralization of guano, bones and coprolites.

Early cave mineralization processes (Hill \& Forti, 1997) are those related to the development of the deposits of the lava channels (Hi12 and Hi13), where soluble sulphates and phosphates where found together with quartz, and even more the sticky stalactites (samples Hi15, Hizz) in which highly soluble minerals like niter and urea have been found together with phosphates, sulphates opal and quartz. The deposition of opal and/or quartz is normal in such an environment because high amount of silica is leached from the volcanic rock by seeping water and the acidification processes (direct consequence of the oxidation of the N-, S-, and P- organic compounds) lead to oversaturation with respect to these minerals.

The Hizz sample is by far more rich in mineralogical species (8) than the Hi15 (4) and this may be explained by the fact that its location was farther away from the area in which the guano firing occurred: in fact the environmental conditions of the stalactites in the Hizz location were less disturbed by the fire and therefore some volatile compounds like niter had the chance to remain and others (quartz, chlorapatite and whitlockite) had the time to develop. On the contrary, it must be stressed that normally the main minerogenetic factor in the Hibashi lava tube has been the guano firing: in fact all the other samples affected by such a phenomenon were those richest in mineralogical species (Hi7 with 15, Hi6B with 10, Hi8 with 8). The relatively lower number of minerals found in the Hi8 sample is justified by the fact that it consists of volcanic rock which was not covered directly by guano or other organic material and the cave minerals found over and inside it were surely deposited by smoke and aerosols and vapours as consequences of the guano burning.

Three of the detected minerals within the burnt samples (pyrocoproite, pyrophosphite and arnhemite) are extremely rare compounds [BPO1] strictly related to guano combustion, which have been observed until now only in few caves of Africa (Martini, 1994a, b; Martini, 1997; Jambor \& Roberts, 1999).

In Hibashi lava tube pyrocoproite and pyrophosphite are by far more common than arnhemite, which has been detected only in sample Hi8. According to the genetic mechanisms for these minerals, arnhemite (Martini 1994a) is not directly produced during the guano-firing event but it is the consequence of the hydration of the minerals developed during the combustion. In its first location (Arnhem Cave, Namibia) arnhemite had the time to develop because the guano-firing occurred over 1500 years ago and also the environmental conditions allowed for enough humidity inside the cave.

Actually no data are available to date the combustion processes inside Hibashi cave, which probably happened in even more recent times. But what is surely different in this lava tube with respect to Arnhem cave is the climate: in fact even if in this area the rainfalls are quite abundant, the relative humidity within the Cave seems to remain always low.

As a consequence hydrated cave minerals (arnhemite, opal and palygorskite) are very few and 
scarce, while other minerals, normally metastable, may survive. This is the case of anhydrite in sample Hi7 and Hi8, which is normally rare in cavern environments because it easily transforms into gypsum, its more stable hydrated compound, which in turn has not been surely detected in Hibashi samples, even if some elements seem to suggest its presence but in very scarce quantity. It is highly probable that Hibashi anhydrite was not the mineral directly produced by the biogenic digestion of the guano and bones (the normal calcium sulphate originated by these mechanisms being gypsum) but it was the final product of the dehydration of gypsum due to the guano firing events.

In conclusion all the evidence from Hibashi cave demonstrates that the evolution of guano-firing minerals to new hydrated compounds is strictly controlled by the amount of available water and therefore gypsum had no way to develop while arnhemite and palygorskite had just a scarce possibility to form.

\section{FINAL REMARKS}

This first and short overview on the cave minerals of Hibashi Cave evidenced the great variety of minerals developing within such a environment thanks to the peculiar conditions which in time made it possible for different minerogenetic mechanisms to become active. Among these the one related to guano combustion is surely the most interesting and allowed a better description of some very rare cave minerals, which where observed only until now in a few caves of Namibia and Romania (Onac \& White, 2003)

Thanks to these findings, the Hibashi lava tube is not only the most important volcanic cave of Saudi Arabia but also by far the richest mineralogical shelter of the country. For this reason, Hibashi Cave has been inserted in the "top ten volcanic caves" for hosted minerals (Forti, 2004). The scarcity of the sampled deposits voided the possibility of defining the chemical composition and mineralogical structure of a new compound which, in the near future, will probably be recognized as a mineral completely new to science.

In conclusion, this research is a further confirmation of the recently advanced opinion that amongst the different cavern environments, the volcanic one is the most favourable for the development of minerogenetic mechanisms (Forti et Al., 1996; Jakobson et Al., 1992; Webb, 1997) and consequently of cave minerals.

\section{ACKNOWLEDGMENTS}

Our thanks to the Saudi Geological Survey and to its president, Dr. Mohammed Tawfiq for continuous support of cave exploration and study in this Country and to Dr. Massimo Tonelli of the C.I.G.S. of the University of Modena and Reggio Emilia for the precious help given at the electronic microscope. 


\section{REFERENCES}

Al Shanti M. A. 2004 The exploration of the Hibashi cave, Saudi Arabia. XI Int. Symp. on Vulcanospeleology, Pico Island, Azores, accepted for presentation.

Forti P. 2004 Minerogenetic processes and cave minerals in volcanic environment: an overview. XI Int. Symp. on Vulcanospeleology, Pico Island, Azores, accepted for presentation.-

Forti P., Panzica La Manna M., Rossi A., 1996 The peculiar mineralogical site of the Alum cave (Vulcano, Sicily) 7th Int. Symp.. Vulcanospeleology, Canarie 1994, p.35-44

Hill C.A., Forti P. 1997 Cave Minerals of the World. Nat. Spel. Soc., Huntsville, USA, 464 pp.

Jakobsson S.B., Jónsson S.S., Leonardsen E. 1992 Encrustations from lava caves in Surtsey, Iceland. A preliminary report. Surtsey Res. Prog. Rep. 10, p.73-78

Jambor J.L.J., Roberts A.C. 1999 New mineral names Am. Miner., 84, p. 193-198.

Jones, J.B. \& Segnit, E.R. 1971 The nature of Opal. I. Nomenclature and constituent phases. J. Geol. Soc. Australia 18, 57-68.

Webb J.A. 1997 Skipton lava tube, Vicotria, Australia in Hill C.A. \& Forti P. Cave Minerals of the world Nat. Spel. Soc., Huntsville, USA, p.331-335

Martini J.E.J. 1994a Two New Minerals Originated from Bat Guano Combustion in Arnhem Cave, Namibia. South African Spel. Ass. Bull. 33, p.66-69.

Martini J.E.J. 1994b The Combustion of Bat Guano - A Poorly Known Phenomenon. South African Spel. Ass. Bull. 33, p.70-72.

Martini J.E.J. 1997 Pyrocoproite $\left(\mathrm{Mg}(\mathrm{K}, \mathrm{Na})_{2} \mathrm{P}_{2} \mathrm{O}_{7}\right.$, monoclinic) a new mineral from Arnhem Cave (Namibia), derived from bat guano combustion. IX Int. Spel. Congr., Le Chaux de Fond, 1, p. 223-225.

Onac B. P., White W. B. 2003 First reported sedimentary occurrence of berlinite $\left(\mathrm{AlPO}_{4}\right)$ in the phosphate-bearing sediments from Cioclovina Cave, Romania. The American Mineralogist, 88: 1395-1397.

Pint J., 2003 The Desert Caves of Saudi Arabi. Stacey International, London, 120 pp.

Pint J. 2004 The lava tubes of Shuwaymis , Saudi Arabia. XI Int. Symp. on Vulcanospeleology, Pico Island, Azores, accepted for presentation.

Smith, D.K. (1998) - Opal, cristobalite, and tridymite: Non crystallinity versus crystallinity, nomenclature of the silica minerals and bibliography. Powder diffraction 13, p. 2-19.

Research made within the MIUR 2002 Project "Morphological and Mineralogical Study of speleothems to reconstruct peculiar karst environments" Resp. Prof. Paolo Forti 
